\title{
Etnografia da roda de choro do Instituto Casa da Cidade
}

Ethnography of Instituto Casa da Cidade's Roda de Choro

Luciana Fernandes Rosa ${ }^{1}$ Ifrosa1@gmail.com http://orcid.org/0000-0001-9889-2809 


\section{Resumo}

Este trabalho apresenta a etnografia de uma roda de choro ocorrida em julho de 2016 no Instituto Casa da Cidade, situado na Vila Madalena, bairro da cidade de São Paulo/SP. A roda em questão, na época realizada mensalmente, era organizada por um músico veterano no cenário do choro paulistano e reunia músicos amadores, profissionais, estudantes e ouvintes. Foram observados aspectos do fazer musical da roda e o perfil de seus participantes sob a perspectiva de alguns autores ligados à etnomusicologia, entre eles Ruth Finnegan, Thomas Turino, John Blacking e Etienne Wenger, por meio da observação participante e entrevistas realizadas com frequentadores do evento. Conclui-se que a roda tem características que a diferem de outras rodas de choro da capital, por ter a participação de músicos amadores e profissionais em um ambiente democrático e acolhedor, e por evidenciar aspectos de resgate da história pessoal dos músicos.

Palavras-chave: choro; etnomusicologia; música popular; música brasileira; antropologia da música.

\section{Abstract}

This paper presents an ethnography of a roda de choro ${ }^{2}$ that occurred in July, 2016, at The Casa da Cidade Institute, located in Vila Madalena, São Paulo. The roda in question, at the time held monthly, was organized by an elderly musician in the scene of the São Paulo choro and brought together amateur musicians, professionals, students and listeners. Aspects of the musical making of the roda and the profile of its participants from the perspective of some authors related to ethnomusicology were observed, among them Ruth Finnegan, Thomas Turino, John Blacking and Etienne Wenger, through participant observation and interviews with attendees of the event. It is concluded that the roda has characteristics that differ from other rodas de choro of the capital, to have the participation of amateur and professional musicians in a democratic and welcoming environment, and for evidencing aspects of rescue of the personal history of the musicians.

Keywords: choro; ethnomusicology; popular music; Brazilian music; anthropology of music.

Doutoranda em Música, Escola de Comunicações e Artes (ECA/USP).

2 Roda de choro is a musical informal gathering, specialized in the gender choro, similar to the jam sessions in jazz, also known as Choro Circle. 


\section{As rodas de choro desde os primórdios e o panorama atual na cida- de de São Paulo}

A roda de choro é um encontro de músicos e apreciadores do gênero com a finalidade de executar músicas pertencentes ao universo do choro e seus gêneros correlatos, como o maxixe, o frevo, a polca, o schottisch, a valsa e o samba. Os primeiros registros de rodas de choro são encontrados no livro de Alexandre Gonçalves Pinto (2014), carteiro e músico amador que viveu entre 1870 e 1940 no Rio de Janeiro, conhecido como "Animal", que publicou em 1936 o mais antigo registro de choros e chorões que se tem notícia. A palavra "choro" era utilizada para denominar as festas onde se encontravam músicos e convidados para tocar e comer. Pinto apresenta o termo desta maneira:

Os Choros - Quem não conhece este nome? Só mesmo quem nunca deu naqueles tempos uma festa em casa. Hoje ainda este nome não perdeu de todo o seu prestígio, apesar de os choros de hoje não serem como os de antigamente, pois os verdadeiros choros eram constituídos de flauta, violões e cavaquinhos, entrando muitas vezes o sempre lembrado oficleide e trombone, o que constituía o verdadeiro choro dos antigos chorões. Naqueles tempos existiam excelentes músicos, que ainda hoje são citados como os cometas que passam de cem em cem anos! (PINTO, 2014, p.11)

Desde então, os encontros de chorões foram se modificando, e suas finalidades também. Novos instrumentos foram introduzidos na roda de choro, como o bandolim, o pandeiro e o saxofone, entre outros. Alguns desapareceram da cena musical, como o oficleide, um instrumento de sopro com chaves e bocal muito comum no século XIX, embora recentemente tenha sido redescoberto por Everson Moraes, que restaurou alguns oficleides e lançou um CD somente com obras escritas por Irineu de Almeida ${ }^{3}$. $O$ choro e seus músicos passaram por um processo crescente de popularização e profissionalização durante o século $X X$, e as reuniões de choro, que aconteciam em ambientes domésticos, começaram a ganhar espaço em apresentações públicas em casas de espetáculos, registros fonográficos e edições de partituras e publicações especializadas. Com o advento do rádio, muitos choros, tradicionalmente um gênero instrumental, ganharam letras e tornaram-se parte do repertório de cantores famosos, como Francisco Alves, Orlando Silva, Aracy Cortes, Aracy de Almeida, Elizeth Cardoso, entre outros.

Atualmente uma roda de choro pode ocorrer em uma residência, seja de um dos músicos ou algum admirador, em bares ou restaurantes, em espaços públicos, como praças ou largos, feiras de antiguidades, centros culturais ou associações desportivas, em escolas de choro ou em diversos outros espaços cedidos para essa finalidade, como o saguão do Teatro Arthur Azevedo, em São Paulo, sede do Clube do Choro de São Paulo, que funcionou entre agosto de 2015 e dezembro de 2016. No estúdio de Silvio Garrido, também na capital paulista, acontece mensalmente a tradicional roda de choro

3 Everson Moraes é um jovem trombonista natural de Cordeiro/RJ que há cerca de cinco anos tem se dedicado ao estudo do oficleide e à pesquisa do repertório escrito para o instrumento, tendo lançado em 2016 um CD e um caderno de partituras com obras de Irineu de Almeida (1863-1914), célebre oficleidista e professor de Pixinguinha. 
encabeçada pelo conjunto regional Izaías e seus Chorões. Também há rodas em lojas de instrumentos musicais, como a loja Contemporânea, em São Paulo, ou Ao Bandolim de Ouro, na cidade do Rio de Janeiro.

Nas rodas que acontecem em residências reina um ambiente de maior informalidade, onde qualquer músico pode e é estimulado a participar e tocar, havendo uma mescla entre profissionais, músicos aposentados, amadores, iniciantes e experientes, assim como cantores. Sobre este tipo de participação, Henrique Cazes afirma que "Uma roda de verdade é aquela que mistura profissionais e amadores, gente que toca melhor ou pior, sem nenhum problema" (CAZES, 1998, p.113). Ruth Finnegan (1989) aborda as definições de amadores e profissionais e fala sobre a complexidade e os significados destas categorizações. Observando o fazer musical em uma pequena cidade no interior da Inglaterra, ela observa que estas separações muitas vezes não dão conta de definir a atuação de um músico, pois ele pode ser considerado profissional, mas, em determinados momentos, prover seu sustento de outras formas que não a música, ou pode ser considerado amador por não viver da música, mas ter uma atuação constante com ela, inclusive tirando proventos, condizente com a carreira de um músico profissional (FINNEGAN, 1989, p.12-14). No caso das rodas de choro, é interessante notar como é complexo definir quem é amador ou quem é profissional, sobretudo porque tradicionalmente os grandes chorões da história sempre tiveram outros empregos, e só recentemente começou a surgir uma classe de profissionais do choro que vivem exclusivamente de música.

Nas rodas que ocorrem em escolas de choro e universidades há predominância do caráter de aprendizado, com professores e alunos participando, sendo a roda uma atividade fundamental e complementar às aulas. Em rodas que ocorrem em bares, existem aquelas onde um conjunto de músicos predefinido recebe pagamento para tocar, evidenciando um caráter de apresentação musical. Nestas apresentações, é estipulado um número certo de participantes, com alguns músicos que podem ser convidados pelo grupo a dar uma "canja" (participação especial). Esta limitação de quantidade e tipo de instrumentistas visa estabelecer um equilíbrio entre os diversos instrumentos acompanhadores e solistas, como também evitar conflitos entre músicos com estilos diferentes e funções distintas na dinâmica da roda. A formação tradicional de uma roda de choro costuma ter um violão de sete cordas e um de seis cordas, um cavaquinho, um ou dois instrumentos solistas, que podem ser sopros e bandolim, e um pandeiro. Normalmente, em uma roda de choro com um nível maior de organização, é permitido apenas um músico tocando pandeiro por vez, sendo que, se há mais pandeiristas presentes, estes se alternam nas músicas. Isto também pode ocorrer com cavaquinhos e violões de sete cordas, outros instrumentos em que podem ocorrer conflitos. No entanto, existem também rodas em bares com um caráter mais aberto, onde a participação é livre para quem quiser tocar. Habitualmente estas rodas são organizadas pelos próprios músicos, com a anuência do proprietário do bar, mas sem pagamento. Os músicos fazem a roda por vontade própria e recebem, como compensação, petiscos e bebidas por conta do 
estabelecimento. Neste caso, não há um número fixo de participantes, e todos os presentes na roda compartilham das comidas e bebidas. É o caso da roda de choro no Bar do Bacalhau, em São Paulo, na zona oeste da capital paulista.

Dentre as rodas de choro que ocorrem em lojas de instrumentos, centros culturais e espaços diversos, não há regra quanto ao número de músicos tocando simultaneamente ou à participação de instrumentistas diversos; estes arranjos são definidos pelos organizadores da roda. Existem ambientes onde há uma abertura maior para a participação de músicos convidados. A tradicional roda de choro do estúdio de Silvio Garrido, conhecido como Silvinho, é uma roda espontânea, sem remuneração, que ocorria todas as sextas-feiras desde 2004 aproximadamente ${ }^{4}$, sendo comandada por um grupo antigo de São Paulo, Izaías e seus Chorões. O conjunto se apresenta regularmente na cidade e usa o espaço da roda também para se manter ativo e ensaiar. Os músicos convidados que participam da roda normalmente chegam munidos de seus instrumentos no local e aguardam o convite de Izaías, bandolinista que é o solista, ou outro músico do conjunto a ingressar na roda. Esses convidados quase sempre são solistas, como flautistas, bandolinistas ou outros instrumentistas de sopro. Nessa roda só há a presença de um violão de sete cordas e um cavaquinho. Quando surgem outros violonistas de sete cordas ou cavaquinistas, estes geralmente se revezam com os músicos do conjunto ou entram na roda quando estes se retiram para descansar ou comer. A Roda do Izaías é um local muito frequentado por aprendizes ou músicos de outros gêneros, como jazz, MPB ou erudito, que admiram o choro e vão observar os músicos. É uma roda onde dificilmente aprendizes ou iniciantes no choro se aventuram a tocar, limitando-se ao papel de observadores. Isto ocorre devido ao alto nível do conjunto e também à atitude pouco paciente de alguns de seus integrantes com os erros e deslizes de outros músicos. Em outros locais, como na roda que ocorria do Clube do Choro de São Paulo, no Teatro Arthur Azevedo, apesar de ser uma roda com um time de músicos contratado semanalmente, havia uma abertura muito maior quanto ao número e nível de participantes e quantidade de instrumentos. Normalmente apenas a regra de um pandeiro era mantida, mas podiam ser permitidos mais cavaquinhos e violões de sete cordas.

\section{A Roda de Choro da Casa da Cidade}

O Instituto Casa da Cidade é uma instituição dedicada à discussão de políticas públicas voltadas à vida no espaço urbano, envolvendo debates, cursos diversos e eventos culturais. O local tem cursos de permacultura ${ }^{5}$ e ciclos de debates sobre o plano diretor municipal e outros assuntos de cunho político, entre outras atividades. Existe desde 2000 e tem como sede uma casa situada à rua Rodésia, no bairro da Vila Madalena, em São Paulo.

\footnotetext{
4 Desde o início de 2018, esta roda passou a ocorrer na primeira sexta-feira de cada mês.

5 Permacultura é um conjunto de atividades que envolve preservação do meio ambiente e sustentabilidade, como compostagem de lixo, captação de água da chuva, cultivo de agroflorestas, entre outras. Ver: http://permacultura.ufsc.br/o-que-e-permacultura/
} 
Desde 19 de setembro de 2014, acontece cerca de uma vez por mês uma roda de choro no local, geralmente em uma quinta-feira. Não existe uma data definida e, devido à agenda de atividades da Casa, o intervalo entre uma roda e outra pode ultrapassar quatro ou cinco semanas. É um evento gratuito, aberto ao público e sua divulgação ocorre por meio de uma lista de e-mail dos frequentadores de edições anteriores da roda. A responsável pela abertura e fechamento da casa e pela divulgação por e-mail é a secretária da Casa, Marjory Mafra. O idealizador e líder da roda é o violonista Nelson Galeano, um veterano do choro de 80 anos que já tocou com importantes nomes da música brasileira, como Waldir Azevedo e Orlando Silva, e é conhecido por ser um grande incentivador de músicos jovens iniciando no choro. Nelson é carinhosamente conhecido por seu apelido de infância, Balói, e é reverenciado por toda a comunidade do choro de São Paulo. Ele promove rodas regularmente em sua casa, na Vila Ipojuca, zona oeste da capital paulista. Balói já foi um músico muito atuante no cenário do choro nas décadas passadas e tem como profissão principal tapeceiro e decorador, ainda em atividade.

Balói sempre apoiou muitos músicos atualmente ativos na carreira, tendo-os acolhido em seus conjuntos ou apresentado a executivos de gravadoras. Foi o caso dos bandolinistas Milton Mori, Aleh Ferreira e Danilo Brito. À parte destes jovens instrumentistas promissores, Balói também sempre deu espaço e estimulou a participação de amigos, iniciantes e amadores nas rodas de choro que frequenta. Balói acredita que a roda é um espaço de interação e aprendizado, sendo o local onde os iniciantes irão aprender e se aperfeiçoar no choro; para ele, este caráter integrador e formador da roda é fundamental. Os erros e o acanhamento são encarados com naturalidade e tolerados como parte do processo de aprendizagem ou limitações naturais do músico, que não deve ser excluído da roda por esta razão.

Em depoimento colhido em julho de 2016, Balói contou que já houve algumas rodas anteriormente na Casa da Cidade, cerca de dez a quinze anos atrás, quando ele promovia dias de roda de choro e outros dias de dança de salão, quando os músicos tocavam samba e outros gêneros dançantes. A versão atual da roda desde 2014 surgiu da necessidade que Balói sentiu de promover uma roda com uma periodicidade definida em um local onde a roda pudesse ser verdadeiramente aberta e inclusiva, com a participação de amigos dele, cantores, músicos iniciantes e profissionais, com comes e bebes trazidos pelos participantes, em um ambiente descontraído e informal, e ao mesmo tempo onde houvesse silêncio por parte da audiência, para que a música fosse ouvida e as conversas não atrapalhassem os músicos. Sobretudo em rodas sem amplificação, o silêncio é fundamental para o andamento da roda. A roda aqui observada é acústica, sem instrumentos amplificados, e a maioria dos presentes participa da roda como músico ou cantor.

Uma outra característica desta roda é a presença forte de cantores, quase todos amigos de longa data de Balói. A atuação de cantores em rodas de choro não costuma ser muito tolerada, sendo que em algumas ela não é sequer permitida, como era o caso da roda do Clube do Choro de São Paulo. O choro é um gênero primordialmente instru- 
mental, mas teve algumas melodias com letras acrescidas posteriormente por letristas e poetas famosos, como Catulo da Paixão Cearense e outros. Existem também muitos sambas e serestas que fazem parte do universo sonoro dos gêneros correlatos ao choro. Para Balói, a presença de cantores na roda é bem-vinda e desejada. Ele afirma em seu depoimento:

Eu acho que samba e choro são dois gêneros que se seguem, sabe, que caminham juntos. Porque o samba é muito difícil, como é o choro, e muito gostoso. Por isso que, quando eu faço a roda, eu chamo cantores também. (Balói, depoimento à autora, 2016).

Sou violoncelista e tenho formação erudita, tendo concluído a graduação e o mestrado em violoncelo. Aprecio e toco choro desde a época de faculdade, e aprendi a tocar violão na infância de maneira autodidata, instrumento que me acompanhou por vários anos de adolescência e juventude. Foi durante a faculdade que comecei a tocar choro no violoncelo, tendo posteriormente aprendido fundamentos do pandeiro nos ritmos do choro. Frequento as rodas na Casa da Cidade desde seu início, em setembro de 2014. Existe um grupo mais ou menos regular de pessoas que a frequentam. Boa parte são casais e amigos e amigas solteiros de Balói de sua faixa etária, em número aproximado de quinze pessoas. Estes participam como cantores, violonistas, cavaquinistas e percussionistas, todos eles amadores. Há também alguns músicos profissionais mais jovens, amigos de Balói, como o flautista Márcio Modesto, o bandolinista Danilo Brito e outros amigos pertencentes ao mesmo círculo de amizade e convívio em rodas e trabalhos profissionais. Há também a presença esporádica de outros músicos, eventualmente convidados estrangeiros, frequentadores das outras atividades da Casa e amigos de Marjory, que recebe os convidados. A roda costuma iniciar-se às $19 \mathrm{~h}$ com poucos presentes, e o número de pessoas aumenta conforme a noite avança. $O$ ápice de frequentadores costuma ser às $22 \mathrm{~h}$, e a partir de meia-noite começa a diminuir, até que finalmente se encerra por volta de uma da manhã, podendo se estender um pouco em ocasiões mais animadas.

Normalmente há uma mesa com alguns petiscos trazidos pelos frequentadores, sendo os maiores colaboradores da parte alimentícia da roda amigos de Balói de longa data. Bebidas alcoólicas são pouco consumidas; um ou outro músico ou frequentador bebe cerveja ou vinho. As pessoas se alternam entre tocar e comer, sendo que a própria configuração de atuantes nas rodas vai sendo definida por quem está tocando ou se ausentou para comer, beber ou descansar.

O espaço físico onde acontece a roda é uma sala grande e quadrada, de aproximadamente trinta metros quadrados. A cozinha se separa deste ambiente apenas por um balcão, sendo que é comum as pessoas ficarem ao redor deste, em seus momentos de comer ou conversar. Na sala tem uma janela grande que dá para a rua, bastante calma neste pedaço do agitado bairro da Vila Madalena, sendo possível para quem passa em frente à casa ouvir o som. 
A dinâmica da roda é bastante variada. Normalmente Balói encaminha e comanda a sucessão de músicas cantadas ou instrumentais, convidando os cantores ou instrumentistas presentes a fazer um solo. Procura alternar blocos cantados e instrumentais, e dentre a parte instrumental também direciona alternância de gêneros, procurando diversificar os estilos e andamentos. Normalmente estes momentos musicais acontecem em blocos de quatro ou cinco músicas, e variam-se também os andamentos, com choros rápidos, outros mais lentos e valsas. Quando um novo instrumentista chega à casa, ele é convidado a iniciar algum solo, normalmente dividindo a música com algum outro solista presente que também a saiba. Por vezes os próprios músicos vão direcionando a dinâmica de acordo com a empolgação, ou sugestão que o próprio repertório executado vai trazendo à roda. Caso perceba que o ritmo se fixou demasiadamente em algum estilo, como choro rápido, lento, valsas ou músicas cantadas, Balói costuma interferir sugerindo que alguém cante ou que se toque uma música de estilo ou andamento contrastantes.

\section{A observação participante em uma roda registrada}

Como participante frequente das rodas na Casa da Cidade, tenho meu registro na memória das várias rodas que presenciei, e para este trabalho registrei em vídeo a roda ocorrida em 7 de julho de 2016. Nessa ocasião optei por apenas observar a roda para me ater a aspectos que normalmente não me são possíveis observar em virtude de participar ativamente como instrumentista. Optei pela metodologia de Blacking (2007), de procurar entender a experiência musical a partir da observação no campo, em conjunto com as minhas impressões e as dos participantes.

Cheguei ao local às $20 \mathrm{~h}$ e havia apenas duas pessoas tocando. Marjory, secretária do Instituto, dois amigos dela frequentadores da Casa e o Sr. Jahyr Pavão, violonista, um dos amigos mais velhos do Balói, conversavam perto do balcão em volume baixo, e tocando estavam o violonista de sete cordas Marco Bertaglia e Daniel, um flautista alemão que passa algumas temporadas no Brasil. Daniel tem um repertório reduzido de choros, embora toque os que sabe com bastante segurança. Foi interessante notar que mesmo com apenas dois músicos a roda se fez presente. Foi minha primeira participação sem tocar na roda, e fui questionada pelos músicos por esta atitude.

Marco é um violonista profissional e muito experiente; procurava sugerir músicas que Daniel soubesse, incluindo aí outros estilos, como bossa-nova, samba, jazz e até alguma do repertório erudito. Passou algum tempo e Sr. Jahyr integrou-se à dupla com seu violão. O próximo a chegar, cerca de meia hora depois, foi Balói, o anfitrião da roda. Cumprimentou-me efusivamente e com seu violão ingressou na roda, que neste momento já se configurava como tal. Seu Jahyr, com a chegada de Balói, trocou o seu violão pelo cavaquinho que também trouxera, para melhor equilibrar a instrumentação. É relativamente comum entre chorões, especialmente os de cordas dedilhadas, tocarem dois ou mais instrumentos, como violão e cavaquinho, ou bandolim e cavaquinho. 
Sucessivamente foram chegando os outros músicos: Marco Bailão, que é um violonista de seis cordas e integrante do grupo do Izaías, foi o próximo; na sequência, por volta de $21 \mathrm{~h}$ chegou Sorriso, um homem de cerca de 60 anos e figura tradicional do choro em São Paulo. Lincoln Sobrinho, seu nome que pouca gente conhece, é uma personagem emblemática do choro; a roda do estúdio do Silvinho, que é seu irmão, é recepcionada por ele, que conhece todos e faz questão de anunciar novos músicos e frequentadores e apresentar as pessoas umas às outras. Sorriso tem um certo déficit cognitivo, porém é bastante independente; locomove-se sozinho e frequenta todas as rodas e eventos de choro de que tem conhecimento. É um amante inveterado do choro e conhece o nome de uma parte considerável do repertório. Aprendeu a tocar bandolim de uma forma particular, dentro de sua capacidade, e possui um repertório de cerca de dez ou quinze músicas, sendo todas valsas ou músicas lentas. Por ter esta limitação de técnica e repertório, Sorriso tem participação restrita nas rodas de choro que frequenta, inclusive na roda que acontece no estúdio de seu irmão. No entanto, a maioria dos chorões de outras rodas de São Paulo permite sua presença, deixando-o tocar algumas músicas. Porém sua participação nas rodas costuma ser pequena, no geral. Sorriso sabe que na Casa da Cidade pode tocar sem sofrer críticas e que Balói é seu incentivador; ainda assim, acredito que ele toca menos do que gostaria, em virtude das longas esperas por uma oportunidade para solar ${ }^{6}$ uma música. No entanto, as pessoas via de regra são amáveis com ele.

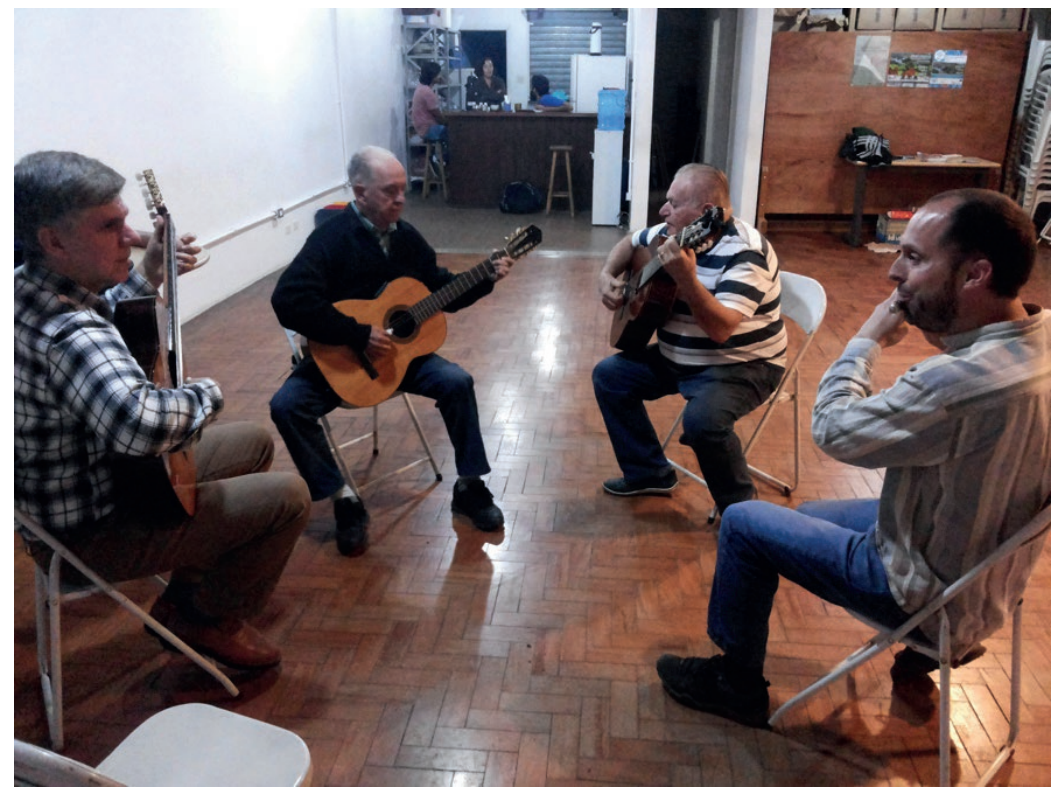

Da esq. para dir.: M. Bertaglia (violão 7),

J. Pavão (violão 6), Balói (violão 7), Daniel (flauta). 
Na sequência chegou a clarinetista carioca e amiga Bia Stutz, que foi convidada por mim por ocasião de sua passagem por São Paulo. Bia é uma ótima instrumentista e bem experiente no choro, com uma atuação expressiva no Rio de Janeiro e na Europa. Assim que chegou, tocou bastante, visto que os outros solistas eram o Daniel, que é iniciante no choro e tem repertório reduzido, e o Sorriso. Depois das $22 \mathrm{~h}$ chegaram os últimos participantes da roda, os flautistas Márcio e Cláudia7, que estavam em um ensaio e por isso foram tardiamente à roda. Neste momento, a roda alcançou seu número máximo de participantes, e o repertório foi bem variado. Márcio é um flautista que atua no choro desde muito jovem, conhecedor de um extenso repertório, e Cláudia é uma flautista de formação erudita que se dedica há alguns anos ao repertório de choro. Bia surpreendeu até a mim cantando algumas músicas, visto que eu desconhecia essa habilidade dela. Dona de uma bela voz, encantou os presentes e imprimiu uma variação inusitada naquela roda de componentes instrumentistas em sua totalidade.

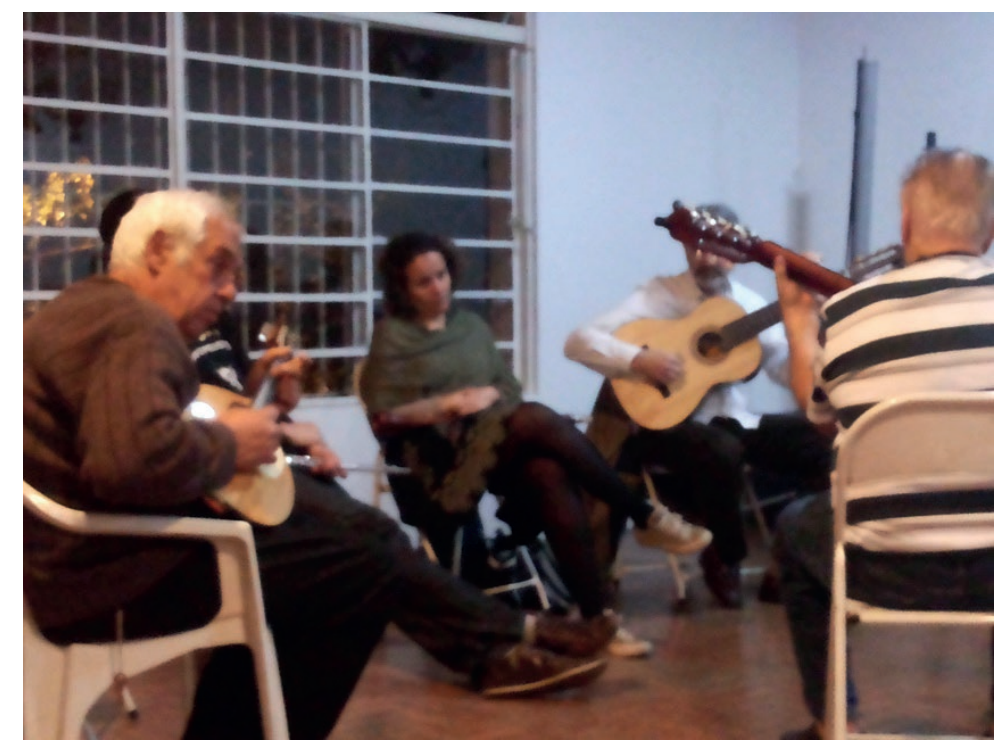

Da esq. para dir.: Sorriso (bandolim), Daniel (flauta),

Bia Stutz (clarinete e voz), M. Bailão (violão 6), Balói (violão 7).

Vale ressaltar que esta foi uma roda bem atípica no perfil das rodas da Casa da Cidade. Dos habituais frequentadores amigos antigos de Balói, apenas um estava presente, o Sr. Jahyr. Foi a primeira roda em que não havia nenhuma das senhoras cantoras habituais. Não compareceu também nenhum pandeirista. Normalmente há um pandeirista profissional que a frequenta e um outro amigo de Balói, um senhor amador que também toca. Lembrando que as primeiras rodas de choro relatadas pelo "Animal" eram compostas por flauta, cavaquinho e violões (PINTO, 2014, p.11), pode-se dizer que esta roda foi espontaneamente a reprodução atual de uma situação muito corriqueira no início das primeiras rodas, ainda que involuntariamente. 


\section{A roda da Casa da Cidade: suas características, depoimentos e re- flexões etnomusicológicas}

A escolha desta roda de choro ocorreu por ela conter uma série de características próprias, que fazem dela ao mesmo tempo uma roda tradicional com alguns elementos singulares. É uma roda tradicional no sentido maior do termo, frequentada por amadores e profissionais; não tem repertório previamente estabelecido, como normalmente ocorre nas rodas; tem um clima de informalidade, configurando uma reunião de amigos e músicos, onde a música tem um papel predominante, mas não exclusivo. $O$ encontro, as conversas, a partilha de petiscos e bebidas, as reminiscências são parte importante e compõem esta roda de maneira característica. No entanto, essa roda tem peculiaridades no cenário atual de rodas de choro na cidade, que não se encontra normalmente em outras rodas: é uma roda de choro onde cantores não só são bem-vindos, como são parte importante e fundamental da roda; conta sempre com a presença de grandes músicos profissionais e de alto nível e ao mesmo tempo de músicos amadores, que só exercem a música em situações como a roda. No entanto, não existe um comportamento repressor na roda por parte dos músicos profissionais e nem os amadores sentem-se intimidados ou constrangidos em participar dela, por ter músicos muito bons participando. Embora alguns profissionais se incomodem com a performance ou técnica incipiente de alguns amadores, este incômodo não é forte o suficiente a ponto de provocar desinteresse nos dos profissionais; sendo assim, eles continuam frequentando a roda. Também não gera comportamentos repressores, como olhares de soslaio ou ataques diretos à pessoa que está se saindo mal em sua performance, nem a expulsão ou exclusão das pessoas da roda por essa razão. Lara Filho et al. (2011) observaram uma tradicional roda de choro durante um ano em uma lanchonete em Brasília e constataram essa exigência de performance satisfatória por parte do grupo que se apresentava regularmente, tanto para com músicos que vinham de fora como até mesmo com participantes da roda que em algum momento tinham uma performance considerada ruim pelo grupo ou um de seus integrantes. Em suas próprias palavras:

Diz-se que a Roda é aberta, ou seja, em princípio, nela é permitida a participação de qualquer músico. A depender do nível técnico e de conhecimento do choro daqueles que a compõem, existe um grau de cobrança de desempenho que pode excluir um grande número de músicos. A Roda da Tartaruga tem marcadamente essa característica. Muitos instrumentistas iniciantes relatam que não têm coragem de tocar, acreditando não possuir nível suficiente para participar. Essa impressão é causada, em parte, porque um bom número dos músicos participantes dela é considerado como os "bons" de Brasília. Também contribui para isso o hábito que os músicos têm de cobrar boas atuações. Não são poupados comentários e brincadeiras; se um participante está a comprometer por demais a execução da música, é solicitado que algum outro músico assuma seu instrumento. Até mesmo músicos frequentes da Roda são alvo de críticas que chegam a ser severas a ponto de criar desentendimentos pessoais (Ex.4). (LARA FILHO et al., 2001, p.156) 
O caso descrito acima refere-se a uma roda que ocorre em um bar, local que a abrigou informalmente há muitos anos, mas que atualmente conta com músicos contratados para tocar. É uma roda aberta, mas conduzida por um elenco fixo. Pode-se concluir que este comportamento do grupo prezando pela qualidade esteja relacionado à necessidade de se manter um nível artístico elevado para a roda, uma vez que o pagamento configura uma relação de trabalho com o dono do estabelecimento. No entanto, este comportamento de se exigir um nível mínimo para performance em rodas também ocorre em outras situações, como a roda do Silvinho, em São Paulo, onde todos tocam por prazer e gratuitamente. É um comportamento típico de rodas de choro, que pode aparecer em maior ou menor grau, mas no caso da roda da Casa da Cidade acontece raramente; é uma característica desta roda, muito porque seu idealizador permite e incentiva músicos amadores e iniciantes a participarem, mas também porque já existe um modus operandi nela que foi sendo estabelecido com o passar do tempo.

É possível pensar nas relações dos frequentadores da roda com a música a partir da visão etnomusicológica de Blacking (2007), para quem a música só faz sentido dentro do contexto social no qual se insere, sendo afetada e afetando-o diretamente, em uma via de mão dupla (BLACKING, 2007, p.201). No caso da roda na Casa da Cidade, é visível este tipo de relação. A música em si é o pretexto para a reunião das pessoas, porém ela não é o objetivo final e é afetada pelas diversas relações presentes. Também segundo o autor, o significado da música está profundamente relacionado ao sentido que a música dá a cada pessoa, pois "[...] os símbolos e os sistemas musicais são socialmente construídos", e " [...] a comunicação musical se torna possível não pelas estruturas musicais per se, mas pelo sentido musical que as pessoas encontram nela" (BLACKING, 2007, p.215). Esta visão da música relacionada ao contexto social também está presente na obra de outros etnomusicólogos como Turino (2008) e Finnegan (1989).

É possível verificar isso no depoimento dos frequentadores e na visão que cada um tem da roda, e qual o significado dela para cada pessoa. Sorriso, por exemplo, é um aficionado por choro e tem uma relação de amor profunda com a música. Em virtude de suas limitações, não exerce nenhuma atividade remunerada e passa os dias dedicando-se a ir em rodas e apresentações, ouvir gravações e praticar seu bandolim. Sobre a roda da Casa da Cidade, ele diz:

Essa roda da Casa da Cidade, na minha opinião, é uma das melhores rodas. De 5áa feira, pra mim, uma das melhor roda. Música é tão gostoso, o chorinho, se desse, eu faria chorinho em todo lugar, em cada cantinho eu faria um grupo de chorinho. Porque eu acho que o chorinho é tão gostoso. Eu gosto de lá por lá tem os melhores músicos, e o ambiente é muito legal. Porque é que nem aqui (fazíamos a entrevista em uma das salas do estúdio de seu irmão), lá não tem barulho, lá é gostoso, tem os grande 7 cordas, na minha opinião, o Marco Bertaglia, o Balói, tem você também que toca violoncelo, uma grande violoncelista, e é isso mesmo. Muito músico bom, muita coisa boa, uma honra tocar lá... Quando eu chego lá, eu toco aquela valsa "Anel de Noivado", "Tema de Lara", tem bastante [...]. Aqui eu não toco. Aqui, quando eu vou tocar, tem músico que sai fora... (Sorriso, em depoimento dado à autora em julho de 2016). 
Nota-se claramente no depoimento de Sorriso sua admiração pelos músicos da roda e sua satisfação em poder se expressar musicalmente naquele ambiente. Além disso, ele tem uma percepção clara de quem é amável e interage bem com ele, conhece muitos dos frequentadores há anos e se sente aceito.

Durante esta roda observada e registrada, ocorreu um episódio com Sorriso que eu nunca tinha presenciado. Em uma das músicas que solava, ele se enganou em um pedaço em que não se ouviu a melodia corretamente. Neste ponto, Marco Bailão, que é membro do grupo do Izaías do Silvinho, chamou sua atenção e disse que ele precisava estudar mais aquela música. Ao que parece, Sorriso não se incomodou muito com o comentário e tampouco o resto do grupo; simplesmente os acompanhadores repetiram aquela parte da música e Sorriso tocou corretamente da segunda vez, e o caso se encerrou. Depois, durante a entrevista, perguntei ao Sorriso o que ela achava do Marco Bailão, e ele disse que ele era "gente boa". Daí pode-se concluir que a atitude do músico de chamar sua atenção durante a roda, porém sem se retirar da mesma, tem um significado muito menos negativo para ele do que músicos que se recusam a acompanhá-lo nos choros que ele toca.

Por outro lado, ouvindo a opinião de Cláudia, uma flautista profissional que estava presente e que costuma frequentar a roda regularmente, notam-se motivações semelhantes e outras diferentes. Para ela, a roda tem momentos musicalmente ruins quando há pessoas tocando pandeiro sem manter o andamento, por exemplo. Porém "o clima descontraído é gostoso", pois ela própria se sente mais à vontade para errar ou tocar alguma música que não domina bem, sem o temor de receber olhares de desaprovação, confirmando a práxis da cobrança de bom desempenho em rodas, sobretudo para músicos mais experientes. Ela compara com a roda comandada pelo Izaías no estúdio do Silvinho, onde fica até "meio feio" caso ela erre, enquanto na Casa da Cidade é mais tranquilo, é uma roda mais light. Esta flautista também mencionou os comes e bebes da roda como um fator interessante e que gera um clima de "confraternização" do evento. Também diz que gosta de ir e ouvir os outros, ficar sentada ouvindo os grandes chorões profissionais (citou Danilo Brito e Márcio Modesto), pois, com isso, conhece outras músicas e amplia seu repertório. Para ela, portanto, a roda tem significados variados. Cita, como motivos das outras pessoas frequentarem a roda, tocar e encontrar os amigos. Ela diz também que para os mais velhos a roda também é um momento de interação social, que muitos são solitários e mais disponíveis, então a roda para eles tem este significado, um momento de sociabilidade. Cláudia cita também o Balói como uma das razões pela qual ela frequenta a roda. Ela diz: “Eu vou lá muito pelo Balói, ele é uma pessoa que eu acho muito agregadora" (Depoimento dado à autora em julho de 2016).

O termo "agregador" também foi utilizado por Marjory em relação a Balói. Ela o vê como uma pessoa muito emotiva, para quem é essencial ter este encontro, pois ele só toca na roda. Nas suas palavras, "é uma pessoa que consegue agregar, juntar". Vê que ele tem uma capacidade grande de agregar e reunir pessoas. Na visão dela, a maioria dos participantes da roda não tem o hábito de estudar ou tocar sozinhos em casa; só fazem música lá ou em outras rodas, e por isso também Marjory ressalta a importância 
da roda na vida dessas pessoas. Conta que Marco Bertaglia sempre a cobra para fazer a roda, para tentar não pular um mês, para as pessoas não desanimarem. Marjory observa que ele parece bem depressivo e solitário, assim como outras pessoas da roda, mulheres e homens, idosos, viúvos, e que às vezes nem querem sair de casa, ou têm dificuldade para vir, e que a roda é fundamental para eles, pois é o momento em que interagem e tocam com os amigos. Ela conta:

\begin{abstract}
Nas primeiras rodas eu ficava extasiada com a qualidade musical e com a dedicação deles com o instrumento. Senti um privilégio quase espiritual de estar ali. Me impressiona o carinho que eles têm um com o outro, e quando eles se encontram eu sinto que faz muito bem pra saúde deles. O Balói, o Marco, o Dárcio, a Margareth, é uma conexão com o passado deles, com a história, as músicas lembram momentos muito felizes da vida deles, parece que eles são "eles" quando eles estão ali, na roda. A vida deles está muito conectada, pois eles viveram muito na noite, viveram muito disso, não sei se profissionalmente, mas hoje é uma oportunidade única de ter uma qualidade musical, com tantos instrumentos, e estar entre amigos, e o silêncio, eles não estão num bar, aqui tem um ambiente silencioso (Marjory Mafra em depoimento à autora, julho de 2016).
\end{abstract}

Em seu depoimento, Marjory também fala sobre o Sorriso, que ele se sente bem lá na Casa, pois não é censurado. Ela entende que a prioridade na roda é estar junto, a amizade, a admiração pela música, e não a qualidade musical, ou a disputa de quem toca melhor. Mas ela percebe também que, quando estão "os tops", os grandes tocando, os mais iniciantes ou amadores até param de tocar, por respeito ou constrangimento. Mas, ainda assim, sente a roda como bastante democrática. Ela inclusive disse que já houve casos de pessoas ou estudantes de música que, passando na rua, ouviram a música, ingressaram na casa e foram bem recebidos na roda. Também percebe que há momentos instrumentais e outros vocais, mas que todos têm espaço. Perguntada sobre a relação entre os amadores e os profissionais, ela enxerga uma relação de troca, de resgatar músicas, um repertório mais antigo, e que esse resgate traz uma dinâmica ao repertório. Sobre as poucas pessoas que vão assistir à roda, ela frisa que apesar de o público gostar muito e ficar impressionado, ela prefere não divulgar muito e chamar apenas os músicos e seus amigos, pois gosta de preservar este momento para eles, pois, se vier muita gente, o nível de ruído fica maior, pois as pessoas se descontraem, começam a beber, conversam e atrapalham a música. Ela própria gosta mais das rodas com menos gente. Sobre a relação da roda com a Casa da Cidade e a programação, ela enxerga a Casa com um perfil diferente; vê como uma diversificação da programação, e que a Casa é um espaço que tem essa possibilidade de acolher o grupo. Ela se sente parte, gosta quando tem, vê a importância de acontecer lá e acolher este grupo. Neste ponto, Marjory confessa que no início, quando houve a proposta de fazer a roda na Casa, até achou um pouco diferente do perfil de atividades e de eventos do local, por ser um espaço mais voltado à discussão de políticas públicas e debates políticos. Porém hoje em dia ela não só enxerga a roda como parte da programação da Casa, como recebe e dialoga com outros grupos que querem usar o espaço, como grupos de dança ou atividades corporais, e vê uma possibilidade de diversificação neste perfil da Casa como 
uma coisa boa, que, além de ocupar horários ociosos, traz um novo leque de atividades interessantes para o local. Sobre a relação do grupo que frequenta a roda com a Casa da Cidade, ela vê mais como a relação deles com o espaço físico. Ela diz que:

Eles se sentem muito bem aqui, eles meio que se sentem na casa deles, um espaço que os acolhe dessa forma, sentem-se muito bem, não sei se por ser a Casa da Cidade, mas pela forma como acontece, é muito simples, acontece com três pessoas, com quatro, cinco, não é um grupo fechado. A roda existe mesmo com pouca gente, não deixa de acontecer. Então acho que eles se sentem super bem. Acho superbacana a relação deles com a Casa. Acho que é um espaço bem tranquilo pra eles, de chegar e tocar. Mesmo se não tem comida, parece que não tem importância. O objetivo principal é tocar (Marjory Mafra em depoimento à autora, julho de 2016).

O depoimento de Balói é longo, não é uma conversa sobre a roda da Casa da Cidade; é sobre o choro, a trajetória dele, a relação com a música, com o tocar, com os jovens que ajudou a se lançarem na carreira. Seu depoimento contém muitas lembranças, momentos emotivos, trazendo à tona quase oito décadas de uma vida musical intensa. Conta que seus dois irmãos tocavam violão e que ele, aos seis anos, começou a mexer nos instrumentos deles para tentar tocar sozinho. Começa a nossa conversa dizendo que na penúltima roda da Casa na época, no último dia de abril de 2016, foi comemorado seu aniversário e foi bastante gente, e que ele achou muito gratificante convidar as pessoas e todas aparecerem. Conta sobre o início da roda naquele local, há cerca de quinze anos, sobre como iniciou no choro, em 1954, pois tocava-se apenas música sertaneja e samba em sua casa. Sobre as razões que o fizeram reiniciar este projeto na Casa da Cidade há dois anos, Balói diz que não há espaços para fazer rodas de choro atualmente em São Paulo, depois que acabou o Bar do Cidão, um reduto tradicional de choro da cidade de São Paulo, que foi vendido recentemente. Em suas palavras, ele diz:

Já faz uns dois anos que faço a roda lá e estamos fazendo de novo lá, sabe, porque tem a roda do Izaías, muito boa e tudo tal, mas lá o pessoal vai mais pra ouvir. Não é a roda que o pessoal entra e toca todo mundo junto, que nem aqui. Eu gosto mais dessa que eu faço. Porque quem chega toca e acabou. Porque aquele que não sabe vai aprendendo, dou chance, dou oportunidade pro cara aprender. E ele entra no meio pra aprender, né, só assim que ele vai aprender. Eu sempre dei oportunidade. Eu via que a pessoa tinha condição e falava: opa, você vai ser o cara. E juro por Deus, de todos que eu apontei, não teve um que eu errei. Todos se destacaram (Nelson Galeano, depoimento à autora, julho de 2016).

Depois Balói descreve todos os músicos jovens que ele incentivou, lembra dessas histórias e se emociona, em alguns momentos o depoimento está entremeado por sua voz embargada e por até momentos de choro contido. Sobre a roda hoje na Casa da Cidade, Balói aposta:

Essa roda a gente tem que fixar o dia certo, porque essa roda tem tudo pra pegar. Porque os chorões adoram tocar em roda de choro, eles não gostam muito de tocar em casa noturna porque têm que tocar o que o pessoal pede, e na roda não, a gente toca tudo quanto é música. Então ali é que eles se completam, né? (Nelson Galeano, depoimento à autora, julho de 2016). 
Sobre o "pessoal da velha guarda", as cantoras, os violonistas, Balói conta que os conhece das rodas de outrora, como a famosa roda do Manoel Andrade, um luthier já falecido, e que foi convidando todos eles para a Casa da Cidade e as mulheres para cantar, pois ele acha que se ficar só o choro é cansativo, que trazer pessoas para cantarem diversifica a roda. Segundo ele:

Pra não ficar só o choro, porque só o choro vai aborrecendo o pessoal, né? Se trouxer gente pra cantar, vai diversificando um pouco, porque você não pode ficar na mesma coisa sempre, ir lá e tocar sempre a mesma coisa, parece disco, né? É verdade, eu não gosto. Eu gosto que vai, e canta música diferente, toca música diferente, a roda eu gosto por causa disso, porque se tocam coisas diferentes, coisa que muita gente não conhece, pode ser choro de cem anos, mas tem gente que nunca ouviu aquilo. É por isso que eu gosto da roda de choro, sabe? Por isso eu sempre fiz roda de choro. Foi assim que eu fui fazendo também, para pessoal que não conhecia o choro ir entrando no choro. E essa garotada que está aí, indiretamente eu sou meio culpado de eles estarem aí, sabe. Só de bandolim, eu fiz uns 4 ou 5 bom, e tão vivendo de música, tão viajando com a música, levando a nossa música pra fora, que é muito importante. Hoje eu vejo e tem israelense, tem chineses, japoneses, todo mundo tocando choro, sabe, isso é uma dádiva pra gente que sempre adorou choro (Nelson Galeano, depoimento à autora, julho de 2016).

Nota-se que Balói também dá muita importância à abertura de pessoas para a roda e incentiva os aprendizes como fonte de disseminação e perpetuação da memória do choro.

Neste dia em que estive na roda como observadora, assim que cheguei, Marco Bertaglia, violonista solista e acompanhador, estava tocando. Balói tem grande admiração por ele e comentou comigo que achava que o Bertaglia ficava tocando o dia inteiro em casa, pois tocava muito bem. Na entrevista, questionei Balói por ter feito aquele comentário e perguntei se ele próprio também não tocava sozinho em casa. Ele me disse que não, porque não é solista, apenas acompanhador, então ele não pratica em casa. Antigamente, como incentivava solistas, ele acabava praticando, pois tocava com eles, mas hoje em dia, como conta:

É mais quando eu vou pra roda, mesmo. Gozado, sempre foi assim, de improviso. Eu chego lá, vamo tocando, vambora. Tem música que eu não conheço, eu paro, não entro no meio. Eles têm eu como um líder, mas eu não sou líder nenhum, não, ali todo mundo que chega lá é líder, sempre respeitando um ao outro. Tem pessoas que vão lá, o Marco Bertaglia, por exemplo, podia ser um líder, porque o que ele toca de violão... O líder tem que ele mandar, ele tem que organizar tudo. Eu acho que pra ser líder tem que nascer líder. Ali a liderança nasce com a pessoa. Eu, todo grupo que eu entrava, eu acabava virando líder, as pessoas me davam a liderança. Eu não chegava pra ser líder, chegava pra ser mais um e virava o líder (Nelson Galeano, depoimento à autora, julho de 2016).

Esta questão da liderança na roda surgiu de uma pergunta minha sobre as atitudes dele na roda de sugerir músicas, mudar o estilo, ao que ele concordou que fazia mesmo, porque quer que todos participem: 
A gente vai vendo que tá ficando só uma coisa, então já "opa, vamos mudar", fazer uma variedade, porque todo mundo que está ali, ninguém veio lá só pra ouvir, porque esse pessoal, graças a Deus, eles vão pra participar também (Nelson Galeano, depoimento à autora, julho de 2016).

Por todos os depoimentos, tanto de um músico profissional como de um amador ou de um ouvinte, percebe-se que a roda tem um significado extremamente importante na vida de todos os frequentadores. No caso de Balói, a necessidade de continuar um espaço de convívio e de aprendizado, onde todos têm espaço e onde há a liberdade para se tocar o que quiser. Para Marjory, a roda é fundamental para o convívio deles, para resgatarem a relação com a música, inclusive como um fator de saúde mental. Vê-se também que a roda ganhou importância para ela própria, não só por enxergar a relevância da roda para os frequentadores, mas por se sentir parte deste grupo, como promotora dele e também por seu apreço pela música e envolvimento pessoal com o clima e as pessoas da roda, assim como por representar um local que tem hoje a missão de acolhê-los. E, para músicos mais jovens, em início de carreira, a troca é interessante, o espaço é mais aberto e tolerante, e também um ambiente de aprendizagem. Para Sorriso, a roda é fundamental como um dos poucos espaços onde ele pode se expressar e onde ele é aceito pelos participantes.

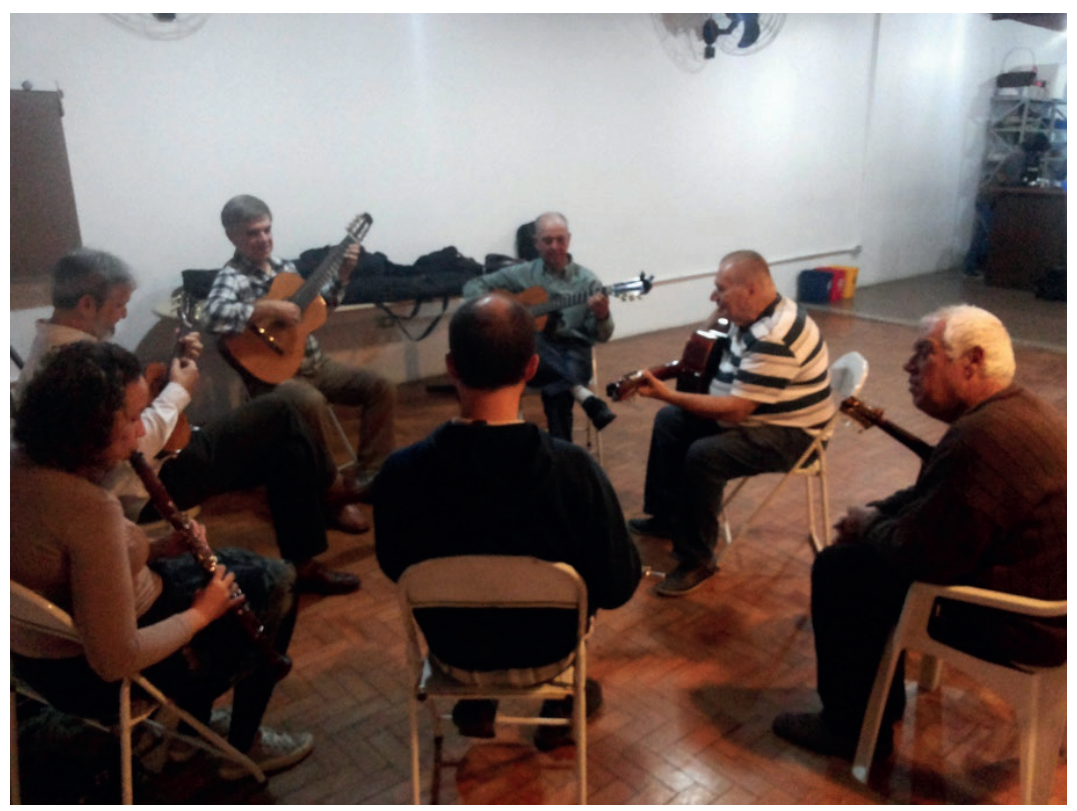

Da esq. para dir.: B. Stutz (clarinete), M. Bailão (violão 6), M. Bertaglia (violão 7),

J. Pavão (villão 6), Balói (violão 7), Sorriso (bandolim), Daniel (flauta).

Turino (2008) postula que a música é parte integrante do processo de integração social das pessoas e também de seu desenvolvimento como um todo (TURINO, 2008 , p.1). Para ele, as manifestações culturais envolvendo música e dança são o caminho mais primário para pessoas articularem suas identidades coletivas, para formarem e articularem os grupos sociais, fundamentais para sua sobrevivência. Estas atividades 
promovem a expressão individual de sentimentos dentro de uma coletividade, o que faz com que os diversos indivíduos que partilham dessa mesma prática e expressão de subjetividade individual tenham um sentimento de pertencimento ao grupo (TURINO, 2008, p.2). Dentro da roda da Casa da Cidade se observa claramente esta afirmação, tanto pelo prazer com que as pessoas vão e cobram a continuidade da roda como pelos depoimentos de Cláudia e Marjory, esta última quando aponta, por exemplo, que Balói precisa da roda para continuar tocando. Essa sensação de pertencimento através da prática do choro está presente em jovens e idosos, amadores, aposentados, profissionais e ouvintes, e por essa razão todos se encontram e confraternizam naquele ambiente.

Como participante da roda, posso relatar também minha relação com ela. Apesar de ter formação sólida em música de concerto, também tenho uma trajetória recente no universo do choro. Tenho uma relação ambígua com a roda da Casa da Cidade. Embora muitas vezes me incomode quando não há um pandeirista habilidoso, na minha concepção, ou com alguém tocando de maneira que não aprecio, gosto do clima agradável que existe lá. Márcio Modesto é um chorão experiente e participa com desenvoltura em qualquer roda de choro, inclusive é bem-vindo na roda do Izaías. Também se incomoda com os momentos de desempenho discutível na roda da Casa, mas geralmente continua frequentando e gosta da roda. Márcio costuma dizer que toda vez que chega na roda e está naquele começo, ainda não tão animado, ele pensa que vai embora logo, mas sempre acaba se envolvendo e ficando até o fim. Acredito que este sentimento de pertencimento ao grupo e à prática compartilhada do fazer musical fica acima do julgamento da qualidade musical da roda como um todo. Vale lembrar que tanto eu quanto Márcio e Cláudia temos formação musical erudita e somos graduados em cursos superiores de Música. Nosso julgamento do que é bom ou ruim em música está diretamente relacionado à nossa formação e expectativas do que seria uma performance musical considerada "boa". Para outros participantes das rodas, estas concepções variam conforme seus próprios valores.

Turino (2008) apresenta o conceito de flow do psicólogo Mihaly Csikszentmihalyi, que é o estado mental de concentração que uma pessoa entra ao se envolver em uma atividade que é desafiadora o suficiente para mantê-la motivada, sem ser exageradamente difícil nem fácil, o que seria desanimador (TURINO, 2008, p.40). Quando está no flow, a pessoa não vê o tempo passar e está presente na atividade. Turino considera que as atividades artísticas e esportivas têm uma propensão grande a provocar o flow, embora este estado possa ocorrer em qualquer tipo de atividade. Acredito que, no fazer musical da roda da Cidade, o flow acontece em um nível individual e coletivo, quando as diferenças de idade, nível musical e expectativas se anulam e todos estão conectados no mesmo fluxo prazeroso de ouvir e fazer música, daí a razão por todos a apreciarem.

Turino (2008, p.16) também discorre sobre a importância do fazer musical dentro do equilíbrio entre o Possível e o Real. O Possível é tudo aquilo que está dentro da esfera do que podemos pensar, realizar ou imaginar, e o Real é o que de fato realizamos, o que fazemos no dia a dia, o que está viável na nossa realidade e rotina, os códigos e 
condutas já conhecidos. O Real seria aquilo que fazemos de fato, e o Possível aquilo que desejamos fazer. Se temos muito apenas do Real, a vida fica monótona e sem significado. Se vivemos apenas na expectativa do Possível, vivemos pouco efetivamente do que já conquistamos (TURINO, 2008, p.17). Para o autor, o campo das artes é um domínio onde a dinâmica entre o Real e o Possível se faz presente e perceptível de uma maneira clara e motivadora (TURINO, 2008, p.18). A experiência artística, portanto, seria o campo onde conectamos as possibilidades futuras da vida com aquilo que já vivemos e experimentamos, tornando o sonhar mais próximo da realização. Um exemplo disso no fazer musical seria a própria experiência de se aprender um instrumento musical, ou, no caso da roda de choro, de tornar Real novamente a vivência musical, seja cantando, tocando, ouvindo ou compartilhando relações. Quando Sorriso se sente bem e acolhido na roda e toca suas músicas, está tornando o Possível em Real e recriando outros Possíveis e outros Reais a cada nova roda. Marjory também observa esta dinâmica nos participantes, na percepção que tem da alegria deles em se encontrarem e resgatarem canções que fizeram parte de sua vida, ou quando protagonizam novamente um fazer que já foi Real, voltou a ser Possível e novamente torna-se Real.

A roda na Casa da Cidade também se encaixa na ideia de uma comunidade de prática de Etienne Wenger (1998). Para este autor, uma comunidade de prática é um grupo de pessoas caracterizado por uma prática em comum e, para ser configurado como tal, necessita ter um compromisso mútuo, um empreendimento em comum e um repertório compartilhado (WENGER, 1998, p.73). Flach e Antonello (2008) definiram bem este conceito da seguinte maneira:

\begin{abstract}
Segundo Wenger (1998), uma prática não existe em abstrato, pois depende de pessoas envolvidas em ações cujo significado é negociado entre as pessoas. Assim, só existe porque estas pessoas pertencem a uma comunidade engajada em concretizar um empreendimento. O empreendimento comum é negociado entre os membros da comunidade a partir de um processo social de negociação que reflete o envolvimento das pessoas na comunidade. O repertório compartilhado é criado pela comunidade aos poucos. A busca conjunta de concretização do empreendimento cria recursos para a negociação de significado. Os elementos do repertório podem ser muito heterogêneos e obtêm sua coerência não como símbolos, atividades ou artefatos específicos, mas sim do fato que eles pertencem à prática de uma comunidade em busca de um empreendimento (FLACH; ANTONELLO, 2008, p.12).
\end{abstract}

Esta ideia de comunidade de prática aplica-se bem à prática musical como um todo, à prática de um gênero específico e também, neste caso particular, ao grupo de pessoas que frequentam as rodas da Casa da Cidade. Wenger também observa que os membros de uma comunidade não necessariamente compartilham de homogeneidade em suas ações ou identidades, e na realidade o grupo é composto de elementos muito diversos; o que os une é o engajamento mútuo (WENGER, 1998, p.75). No caso da roda da Casa da Cidade, é visível esta diversidade, inclusive de motivações que fazem as pessoas frequentarem a roda. Enquanto para alguns é um evento social, como diz Marjory, para outros é um momento de fazer música de uma maneira mais tranquila e conhecer 
o repertório, e até mesmo ir numa festa e comer bem, como para Cláudia. Para Balói, é a continuidade da sua história de vida, do choro, a manutenção da memória, o encontro de gerações e o aprendizado; para Marjory, é a preservação de relações de amizade e fazer musical, e assim por diante. Estas motivações muitas vezes se entrelaçam e se combinam entre as pessoas. Para Wenger, embora o engajamento mútuo não crie homogeneidade, ele promove relações entre as pessoas. Estas relações são muitas vezes caracterizadas por tensões e conflitos (WENGER, 1998, p.76-77), como se observa na roda: o músico que é repreendido, o cantor que não foi convidado, o pandeirista que não tocou durante a roda toda, o flautista que se irritou com o andamento caindo, o ouvinte que foi advertido por conversar fazem parte dessa comunidade e dessa prática.

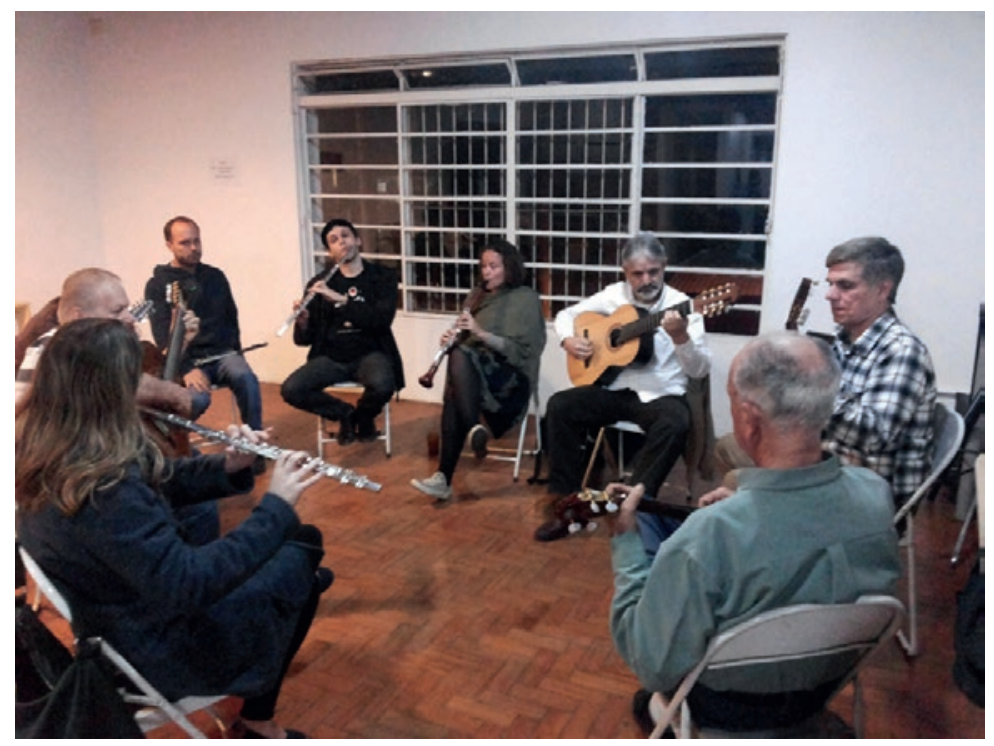

Da esq. para dir.: Cláudia (flauta), Balói (violão de 7), Daniel (fauta), M. Modesto (flauta),

B. Stutz (clarinete), M. Bailão (violão de 6), M. Bertaglia (violão de 7), J. Pavão (cavaquinha).

Finnegan (1998) também dedicou seu trabalho ao fazer musical dos músicos "escondidos", ou os músicos considerados "amadores", como um coro e bandas na cidade de Milton Keynes, no Reino Unido, tipos de formações que usualmente não são objeto de estudo por parte de estudiosos da música (FINNEGAN, 1998, p.4-5). A autora preferiu direcionar seu estudo, ao invés dos produtos musicais, como obras musicais ou performances, à prática musical e aos processos como um todo destes grupos considerados amadores (FINNEGAN, 1998, p.8). No caso de um grupo coral, o Sherwood Choir, Finnegan observou como todos os processos que envolvem a atividade do coro são fundamentais para a implementação e permanência deste. Estes processos incluem desde a definição do local de ensaios, a convocação de músicos, os arranjos que cada um tem que fazer para comparecer, o momento do cafezinho e tudo que o envolve, até as apresentações, divulgações, afinação do piano, entre muitos outros fatores A autora observa que o fazer musical de grupos amadores, que não é sustentado por grandes corporações ou organizações governamentais, necessita de um intenso trabalho em 
equipe que envolve os próprios componentes para que se sustente, às vezes muito mais que grupos profissionais, e, por essa razão, estudar estes processos é necessário para se compreender a continuidade dessas práticas musicais (FINNEGAN, 1998, p.236-254).

Na roda da Casa da Cidade também se observa fortemente todo o esforço necessário para que ela aconteça: desde a negociação para sua implementação, no início, com a conversa para a utilização da Casa como espaço da roda; o envolvimento gradativo da Marjory, que prepara o espaço e também se responsabiliza pela divulgação por e-mail e convite por telefone para algumas pessoas; a conciliação com as datas das atividades da casa e até a escolha do dia, para que não haja conflito com outras rodas de choro na cidade; a presença de músicos-chave, como um violonista seguro, sem o qual não acontece a roda; a necessidade de um ambiente silencioso, e para isso há que se fazer uma seleção de convidados, como Marjory observou; a preparação da comida e compra de bebidas pelos frequentadores; a limpeza durante e após as rodas; o registro, o compartilhamento de fotografias e vídeos; na parte musical, o equilíbrio de instrumentos, a distribuição de músicas, a condução dos momentos musicais, a vontade de se convidar mais músicos e fazer a roda mais conhecida. São muitos fatores que compõem a complexidade de se manter uma atividade como esta, que acontece pela vontade dos músicos, pela colaboração do Instituto e de Marjory.

\section{Conclusões}

Estes relatos e estas reflexões procuraram compreender um pouco os processos musicais e sociais de uma roda de choro específica da cidade de São Paulo. Por meio da observação da roda, das minhas lembranças de rodas anteriores, das impressões e opiniões de frequentadores e de depoimentos recolhidos e dos referenciais teóricos de antropólogos e outros estudiosos do choro, pude concluir que a roda da Casa da $\mathrm{Ci}$ dade hoje se configura como uma autêntica roda de choro aberta, democrática e profundamente importante na vida dos que a frequentam. A importância da roda se dá por diversas razões, na medida em que perpetua o gênero choro e outros correlatos, e por proporcionar o protagonismo de pessoas para quem o choro e a música têm profunda relevância na vida, o encontro de gerações, a realização pessoal e a continuidade do choro, uma prática musical que é parte integrante da história da nação.

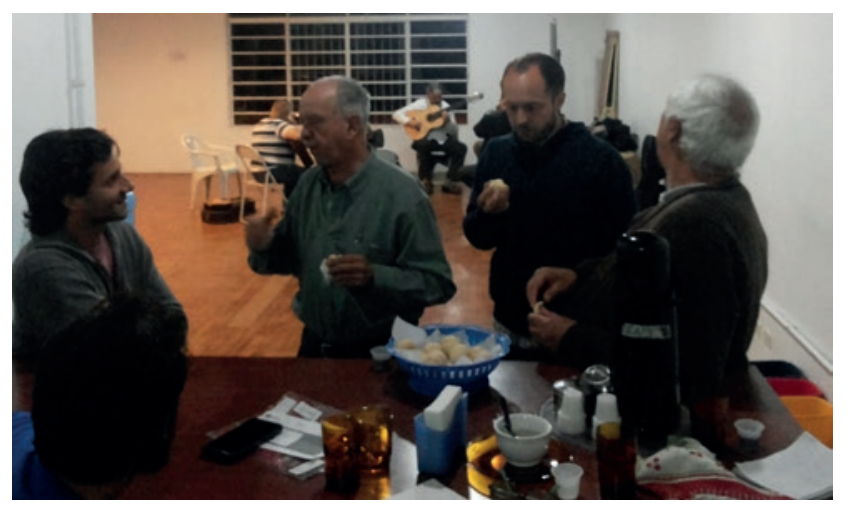

Ouvinte e músicos comendo e bebendo 


\section{Referências}

BLACKING, J. Música, cultura e experiência. Cadernos de Campo, n. 16, p. 201218, 2007. Disponível em: http://www.revistas.usp.br/cadernosdecampo/article/ view/50064.

CAZES, H. Choro: do quintal ao Municipal. São Paulo: Editora 34, 1998.

FINNEGAN, R. The hidden musicians: making-music in an English town. Cambridge: Cambridge University Press, 1989.

FLACH, L.; ANTONELLO, C. S. Improvisação e aprendizagem nas organizações: reflexões a partir da metáfora da improvisação no teatro e na música. In: ENCONTRO NACIONAL DA ASSOCIAÇÃO NACIONAL DOS PROGRAMAS DE PÓS-GRADUAÇÃO EM ADMINISTRAÇÃO, 32., 2008, Rio de Janeiro. Anais [...]. Rio de Janeiro: Anpad, 2008. Disponível em: http://www.anpad.org.br/admin/pdf/EOR-B755.pdf. Acesso em: 15 fev. 2019.

LARA FILHO, I. G.; SILVA, G. T. da; FREIRE, R. D. Análise do contexto da Roda de Choro com base no conceito de ordem musical de John Blacking. Per Musi, Belo Horizonte, n. 23, p. 148-161, 2011.

PINTO, A. G. O choro: reminiscências dos chorões antigos. 3. ed. rev. e com. Rio de Janeiro: Acari Records, 2014 [1936].

TURINO, T. Music as social life: the politics of participation. Chicago: The University of Chicago Press, 2008.

WENGER, E. Communities of practice: learning, meaning and identity. Cambridge University Press, 1998.

Vídeos da roda

http://www.youtube.com/watch?v=uAxQbyEqLm8

http://www.youtube.com/watch?v=gXOkPAjMxi4

https://www.youtube.com/watch?v=5MEPKOK $5 \mathrm{~s} 8 \mathrm{Q}$ 